Keywords: cutaneous squamous cell carcinoma; MAPK pathway; actinic keratosis; expression microarray profiling; differentiation status; skin cancer

\title{
Key differences identified between actinic keratosis and cutaneous squamous cell carcinoma by transcriptome profiling
}

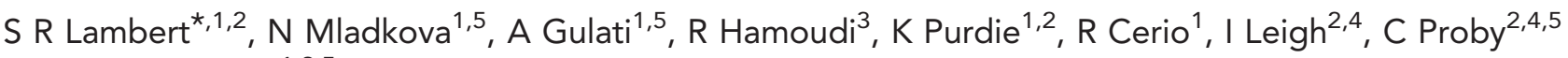 \\ and C A Harwood ${ }^{1,2,5}$
}

${ }^{1}$ Centre for Cutaneous Research, Blizard Institute, Barts and the London School of Medicine and Dentistry, Queen Mary University of London, London, UK; ${ }^{2}$ Cancer Research UK Skin Tumour Laboratory, Blizard Institute, Barts and the London School of Medicine and Dentistry, Queen Mary University of London, London, UK; ${ }^{3}$ Research Department of Pathology, Cancer Institute, Faculty of Medical Sciences, University College London, London WC1E 6BT, UK and ${ }^{4}$ Skin Tumour Laboratory, Division of Cancer Research, Jacqui Wood Cancer Centre, Ninewells Hospital and Medical School, University of Dundee, Dundee DD1 9SY, UK

Background: Cutaneous squamous cell carcinoma (CSCC) is one of the most common malignancies in fair-skinned populations worldwide and its incidence is increasing. Despite previous observations of multiple genetic abnormalities in cSCC, the oncogenic process remains elusive. The purpose of this study was to elucidate key molecular events associated with progression from premalignant actinic keratoses (AKs) to invasive cSCC by transcriptome profiling.

Methods: We combined laser capture microdissection with the Affymetrix HGU133 Plus 2.0 microarrays to profile 30 cSCC and 10 AKs.

Results: We identified a core set of 196 genes that are differentially expressed between AK and cSCC, and are enriched for processes including epidermal differentiation, cell migration, cell-cycle regulation and metabolism. Gene set enrichment analysis highlighted a key role for the mitogen activated protein kinase (MAPK) pathway in CSCC compared with AK. Furthermore, the histological subtype of the tumour was shown to influence the expression profile.

Conclusion: These data indicate that the MAPK pathway may be pivotal to the transition from AK to CSCC, thus representing a potential target for CSCC prevention. In addition, transcriptome differences identified between cSCC subtypes have important implications for future development of targeted therapies for this malignancy.

Skin cancers are by far the most common malignancies in fairskinned populations, with an incidence now reaching epidemic proportions (Madan et al, 2010; Rogers et al, 2010). There are $\sim 700000$ cases of cutaneous squamous cell carcinoma (cSCC) diagnosed each year in the United States and the frequency is rising worldwide (de Vries et al, 2005; Skin Cancer Foundation, 2010). While the overall survival of patients with CSCC is high, these tumours are associated with considerable morbidity and pose a substantial financial burden for health-care systems. When cSCC metastasises, the prognosis is poor, with a 5-year survival rate of $<25 \%$ (Rowe et al, 1992; Kraus et al, 1998). Immunosuppressed patients such as organ transplant recipients (OTRs) and individuals with chronic lymphocytic leukaemia are at significantly increased risk for CSCC and are prone to multiple and often aggressive tumours (Euvrard et al, 2003; Harwood et al, 2006, 2013).

An estimated 65\% of cSCC arise from precursor lesions termed actinic keratoses (AKs) (Criscione et al, 2009). Actinic keratosis is associated with epidermal atypia and is thought to represent a

*Correspondence: Dr SR Lambert; E-mail: sally_lambert40@hotmail.com
${ }^{5}$ These authors contributed equally to this work.

Received 16 June 2013; revised 25 October 2013; accepted 7 November 2013; published online 12 December 2013 
continuum of progression from dysplastic keratinocytes to cSCC. Actinic keratoses affect up to $18 \%$ of people in the United Kingdom over 60 years of age, rising to $64 \%$ in Australia (Frost et al, 2000; Memon et al, 2000). They are the strongest independent risk factor for cSCC development, and often present as multiple lesions, producing 'field cancerisation' if confluent. The precise rate of progression is unknown, however, a study from the United States that prospectively followed 169 patients with a total of 7784
AK estimated the risk of progression for an individual lesion was $2.57 \%$ at 4 years (Criscione et al, 2009). Evidence for progression of $\mathrm{AK}$ to $\mathrm{CSCC}$ is also provided by genetic studies that report AKs have a similar karyotypic profile to cSCC, but display a reduced degree of complexity, consistent with an earlier stage of tumour development (Ashton et al, 2003).

Despite the frequency of cSCC, their underlying molecular pathogenesis is poorly characterised, especially the changes

\section{Table 1. Sample characteristics}

\begin{tabular}{|c|c|c|c|c|c|c|c|}
\hline Sample name & AK/SCC & Patient no. & Differentiation status & Immune status & Gender & Location & Age (years) \\
\hline AK1 & AK & 8 & NA & IC & M & Leg & 52 \\
\hline AK2 & $A K$ & 10 & NA & IS & M & Scalp & 65 \\
\hline AK3 & $A K$ & 9 & NA & IS & M & Hand & 69 \\
\hline AK4 & AK & 11 & NA & IC & M & $\mathrm{R}$ hand & 89 \\
\hline AK5 & AK & 2 & NA & IS & $\mathrm{F}$ & Hand & 71 \\
\hline AK6 & AK & 1 & NA & IS & $\mathrm{M}$ & Hand & 63 \\
\hline AK7 & AK & 4 & NA & IS & $M$ & Hand & 57 \\
\hline AK8 & $A K$ & 5 & NA & IS & M & Hand & 57 \\
\hline AK9 & AK & 6 & NA & IS & M & Scalp & 72 \\
\hline AK10 & $A K$ & 7 & NA & IC & $M$ & Hand & 80 \\
\hline SCC1 & SCC & 1 & WD & IS & $M$ & Elbow & 63 \\
\hline SCC2 & SCC & 2 & WD & IS & $F$ & Hand & 69 \\
\hline $\mathrm{SCC} 3$ & SCC & 3 & WD & IC & $M$ & Calf & 74 \\
\hline SCC4 & SCC & 4 & WD & IS & $M$ & Upper arm & 56 \\
\hline SCC5 & $\mathrm{SCC}$ & 5 & WD & IS & $M$ & Hand & 49 \\
\hline SCC6 & SCC & 9 & WD & IS & $M$ & Scalp & 70 \\
\hline SCC7 & $\mathrm{SCC}$ & 10 & WD & IS & $M$ & Temple & 64 \\
\hline SCC8 & SCC & 11 & WD & IC & $M$ & Temple & 88 \\
\hline SCC9 & SCC & 14 & WD & IC & $M$ & Temple & 77 \\
\hline SCC10 & SCC & 15 & WD & IC & $M$ & Pinna & NA \\
\hline SCC11 & SCC & 16 & WD & IS & $M$ & Neck & 30 \\
\hline SCC12 & SCC & 22 & WD & IS & $M$ & Scalp & 56 \\
\hline SCC13 & $\mathrm{SCC}$ & 23 & WD & IS & $\mathrm{F}$ & Finger & 47 \\
\hline SCC14 & SCC & 30 & WD & IC & $M$ & Groin & 67 \\
\hline SCC15 & SCC & 31 & WD & IS & $M$ & Forearm & 46 \\
\hline SCC16 & SCC & 6 & MD & IS & $M$ & Pinna & 73 \\
\hline SCC17 & $\mathrm{SCC}$ & 8 & MD & IC & $M$ & Chest & 52 \\
\hline SCC18 & $\mathrm{SCC}$ & 17 & $\mathrm{MD}$ & IC & $M$ & Temple & 77 \\
\hline SCC19 & SCC & 21 & MD & IS & $\mathrm{F}$ & Shin & 66 \\
\hline SCC20 & SCC & 24 & W-MD & IS & $M$ & Pinna & 80 \\
\hline SCC21 & SCC & 25 & $\mathrm{MD}$ & IS & $M$ & Pinna & 58 \\
\hline SCC22 & SCC & 26 & $\mathrm{MD}$ & IS & $M$ & Neck & 41 \\
\hline SCC23 & SCC & 27 & $\mathrm{MD}$ & IS & $M$ & Chest & 51 \\
\hline SCC24 & $\mathrm{SCC}$ & 28 & $M D$ & IC & $M$ & Temple & 69 \\
\hline SCC25 & SCC & 12 & M-PD & IC & $F$ & Calf & 86 \\
\hline SCC26 & SCC & 13 & M-PD & IS & $\mathrm{F}$ & Finger & 59 \\
\hline SCC27 & SCC & 18 & M-PD & IS & $\mathrm{F}$ & Foot & 73 \\
\hline SCC28 & SCC & 19 & PD & IS & $M$ & Cheek & 75 \\
\hline SCC29 & SCC & 20 & $P D$ & IS & $M$ & Pinna & 68 \\
\hline SCC30 & SCC & 29 & M-PD & IS & $M$ & Neck & 67 \\
\hline
\end{tabular}


involved in progression from $\mathrm{AK}$ to cSCC. Recent exome-level sequencing of cSCC revealed a huge mutational burden of $\sim 1$ per 30000 base pairs of coding sequence (Durinck et al, 2011). This makes cSCC the most highly mutated human malignancy, compounding the difficulty in defining 'driver' molecular events underlying their development. Evidence to date supports important tumour suppressor roles for TP53 and NOTCH, but the contribution of additional genes and pathways is unclear (Durinck et al, 2011; Wang et al, 2011). Earlier studies demonstrated considerable karyotypic complexity in cSCC, with frequent gains on chromosomes 3q, 8q and 20q and losses of 3p, 4p, 9p, 13q, 17p and 17q (Quinn et al, 1994; Popp et al, 2002; Ashton et al, 2003; Clausen et al, 2006; Purdie et al, 2007, 2009). Our previous genome-wide analysis using single-nucleotide polymorphism (SNP) microarrays revealed that well-differentiated (WD) tumours display a distinct genetic profile from moderately (MD) and poorly differentiated (PD) tumours, indicating that these may represent a separate subgroup of cSCC (Purdie et al, 2009). However, current published expression microarray studies have failed to corroborate this at the level of gene expression and have yielded little consensus on the genes that are differentially expressed in cSCC (Van Haren et al, 2009). This can be largely attributed to small sample sizes, non-microdissected tumour specimens and the absence of correlation with cSCC grade among the tumours analysed (Haider et al, 2006; Kathpalia et al, 2006; Nindl et al, 2006).

The purpose of our study was to identify potential 'drivers' in the transition from AK to cSCC by comparing the transcriptome of tumour cells isolated by laser capture microdissection from cSCC, with that of dysplastic keratinocytes from AKs. We have identified a series of differentially expressed genes (DEGs) in cSCC and have demonstrated key biological processes that distinguish cSCC from AK. Furthermore, an enrichment of DEGs has been demonstrated in key pathways such as the mitogen activated protein kinase (MAPK) pathway, implicating this pathway in the evolution of cSCC from precursor lesions.

\section{MATERIALS AND METHODS}

Tumour samples. Fresh-frozen biopsies of normal skin, AK and cSCC were obtained at the time of surgical excision and immediately snap-frozen in liquid nitrogen. All patients provided informed consent in accordance with ethical approval from the East London and City Health Authority local ethics committee. For microarray analysis, patient material was preferentially included where matched AK and CSCC lesions were available from the same patient. Subsequent samples were chosen to represent a range of histological diagnoses from both immunosuppressed and immunocompetent patients. In total, $10 \mathrm{AKs}$ and 30 primary cSCC (9 matched to AK) were analysed. The cSCC comprised $15 \mathrm{WD}$, $9 \mathrm{MD}$ (including 1 cSCC admixed with an additional WD component, W-MD) and 6 PD (including 4 cSCC admixed with an $\mathrm{MD}$ component, M-PD). The samples were derived from 10 immunocompetent patients, 20 OTRs and 1 patient with chronic lymphocytic leukaemia, reflecting the spectrum of patients presenting with cSCC to our institution. Patient and sample characteristics are detailed in Table 1.

Expression microarray analysis. Laser capture microdissection and RNA extraction were performed as previously described (Lambert et al, 2012), such that all samples were estimated to be a minimum $90 \%$ enrichment for tumour or dysplastic cells. RNA quality and concentration was measured using the Agilent Bioanalyser (Agilent, Berkshire, UK). Ten nanograms of RNA was used as a template for whole transcriptome amplification and cDNA synthesis using the NuGen WT-ovation Pico RNA Amplification System according to the manufacturer's instructions
(NuGen, San Carlos, CA, USA). Five micrograms of amplified cDNA was labelled with the FL-ovation Biotin Kit (NuGen) and hybridised to the Affymetrix HGU133 Plus 2.0 microarrays (Affymetrix, Santa Clara, CA, USA), comprising 54675 features.

Table 2A. Differentially expressed genes downregulated between AK and CSCC, as identified by both ANOVA and eBayes

$$
\text { Ger }
$$

\begin{tabular}{|l|c|c|l|c|c|}
\hline $\begin{array}{l}\text { Gene } \\
\text { name }\end{array}$ & $\begin{array}{c}\text { Log2 } \\
\text { FC }\end{array}$ & $\begin{array}{c}\text { Adj } \\
\boldsymbol{P} \text {-value }\end{array}$ & $\begin{array}{l}\text { Gene } \\
\text { name }\end{array}$ & $\begin{array}{c}\text { Log2 } \\
\text { FC }\end{array}$ & $\begin{array}{c}\text { Adj } \\
\boldsymbol{P} \text {-value }\end{array}$ \\
\hline FLG2 & -6.0 & $2.96 \mathrm{E}-02$ & LOC283070 & -2.2 & $3.36 \mathrm{E}-03$ \\
\hline
\end{tabular}

\begin{tabular}{|l|l|l|l|l|l|}
\hline FLG2 & -6.0 & $2.96 \mathrm{E}-02$ & LOC283070 & -2.2 & $3.36 \mathrm{E}-03$ \\
\hline KRT9 & -5.8 & $8.31 \mathrm{E}-04$ & SEPP1 & -2.1 & $1.57 \mathrm{E}-02$ \\
\hline
\end{tabular}

\begin{tabular}{|l|l|l|l|l|l|}
\hline KRT77 & -5.4 & $8.31 \mathrm{E}-04$ & SERTAD4 & -2.0 & $1.34 \mathrm{E}-03$ \\
\hline
\end{tabular}

\begin{tabular}{|l|l|l|l|l|l|}
\hline FLG & -5.3 & $3.30 \mathrm{E}-02$ & GLDN & -1.9 & $2.87 \mathrm{E}-02$ \\
\hline
\end{tabular}

\begin{tabular}{|l|c|c|l|l|l|}
\hline LOR & -5.2 & $1.73 \mathrm{E}-02$ & UBL3 & -1.9 & $3.34 \mathrm{E}-03$ \\
\hline LCE1B & -5.2 & $3.67 \mathrm{E}-02$ & LYPLAL1 & -1.9 & $2.41 \mathrm{E}-02$ \\
\hline
\end{tabular}

\begin{tabular}{|l|c|c|l|c|c|}
\hline LCE1B & -5.2 & $3.67 \mathrm{E}-02$ & LYPLAL1 & -1.9 & $2.41 \mathrm{E}-02$ \\
\hline SERPINB12 & -5.2 & $1.55 \mathrm{E}-02$ & ARL5A & -1.8 & $8.24 \mathrm{E}-03$ \\
\hline AZGP1 & -4.9 & $6.23 \mathrm{E}-04$ & HNRPLL & -1.8 & $3.14 \mathrm{E}-02$ \\
\hline
\end{tabular}

\begin{tabular}{|l|l|l|l|l|l|}
\hline AZGP1 & -4.9 & $6.23 \mathrm{E}-04$ & HNRPLL & -1.8 & $3.14 \mathrm{E}-02$ \\
\hline CD36 & -4.7 & $5.44 \mathrm{E}-04$ & BOC & -1.8 & $7.15 \mathrm{E}-03$ \\
\hline AADACL2 & -4.1 & $1.43 \mathrm{E}-02$ & GGTA1 & -1.8 & $2.91 \mathrm{E}-02$ \\
\hline
\end{tabular}

\begin{tabular}{|l|l|l|l|l|l|}
\hline HPGD & -3.8 & $3.22 \mathrm{E}-03$ & ELOVL6 & -1.7 & $4.14 \mathrm{E}-03$ \\
\hline SERPINA12 & -3.6 & $4.57 \mathrm{E}-02$ & SPATA6 & -1.7 & $1.07 \mathrm{E}-02$ \\
\hline
\end{tabular}

\begin{tabular}{|l|l|l|l|l|l|}
\hline TNFRSF19 & -3.3 & $4.82 \mathrm{E}-02$ & C10rf96 & -1.7 & $2.05 \mathrm{E}-03$ \\
\hline MUC15 & -3.3 & $6.07 \mathrm{E}-03$ & IDE & -1.7 & $1.44 \mathrm{E}-02$ \\
\hline
\end{tabular}

\begin{tabular}{|l|l|l|l|l|l|}
\hline MFAP3L & -3.3 & $1.63 \mathrm{E}-02$ & CREBL2 & -1.7 & $1.55 \mathrm{E}-03$ \\
\hline ATP6V1C2 & -3.2 & $4.90 \mathrm{E}-03$ & PGRMC2 & -1.6 & $3.43 \mathrm{E}-02$ \\
\hline ELOVL4 & -3.1 & $3.34 \mathrm{E}-03$ & KRT10 & -1.6 & $1.51 \mathrm{E}-02$ \\
\hline
\end{tabular}

\begin{tabular}{|l|l|l|l|l|l|}
\hline ELOVL4 & -3.1 & $3.34 \mathrm{E}-03$ & KRT10 & -1.6 & $1.51 \mathrm{E}-02$ \\
\hline BPIL2 & -3.1 & $3.46 \mathrm{E}-03$ & SLC30A1 & -1.6 & $7.91 \mathrm{E}-04$ \\
\hline
\end{tabular}

\begin{tabular}{|l|c|c|l|l|l|}
\hline BPIL2 & -3.1 & $3.46 \mathrm{E}-03$ & SLC3OA1 & -1.6 & $7.91 \mathrm{E}-04$ \\
\hline TGFBR3 & -3.0 & $5.44 \mathrm{E}-04$ & ZDHHC23 & -1.5 & $1.55 \mathrm{E}-02$ \\
\hline EDNRB & -2.9 & $1.82 \mathrm{E}-05$ & TMEM45A & -1.5 & $3.36 \mathrm{E}-03$ \\
\hline PDZD2 & -2.9 & $1.55 \mathrm{E}-03$ & ATP7A & -1.5 & $1.45 \mathrm{E}-02$ \\
\hline
\end{tabular}

\begin{tabular}{|l|c|l|l|l|l|}
\hline PDZD2 & -2.9 & $1.55 \mathrm{E}-03$ & ATP7A & -1.5 & $1.45 \mathrm{E}-02$ \\
\hline ITM2A & -2.9 & $1.67 \mathrm{E}-02$ & C5Orf41 & -1.5 & $3.86 \mathrm{E}-02$ \\
\hline MARCH3 & -2.8 & $7.15 \mathrm{E}-03$ & KIAA1370 & -1.5 & $7.15 \mathrm{E}-03$ \\
\hline LAMB4 & -2.8 & $4.69 \mathrm{E}-02$ & OLFM2 & -1.4 & $3.86 \mathrm{E}-02$ \\
\hline EGR3 & -2.7 & $7.76 \mathrm{E}-03$ & PARM1 & -1.4 & $2.25 \mathrm{E}-02$ \\
\hline ZNF682 & -2.7 & $1.53 \mathrm{E}-02$ & TCP11L2 & -1.4 & $8.24 \mathrm{E}-03$ \\
\hline METTL7A & -2.6 & $1.21 \mathrm{E}-03$ & SECISBP2L & -1.3 & $1.64 \mathrm{E}-02$ \\
\hline RORA & -2.6 & $5.18 \mathrm{E}-04$ & MIPEP & -1.3 & $3.66 \mathrm{E}-02$ \\
\hline QPCT & -2.5 & $1.19 \mathrm{E}-02$ & OXCT1 & -1.3 & $2.87 \mathrm{E}-02$ \\
\hline LGR6 & -2.5 & $2.19 \mathrm{E}-02$ & ATAD2B & -1.3 & $3.72 \mathrm{E}-02$ \\
\hline ID4 & -2.5 & $3.28 \mathrm{E}-02$ & CNOT6L & -1.2 & $2.32 \mathrm{E}-02$ \\
\hline HLF & -2.5 & $4.57 \mathrm{E}-03$ & SLC26A11 & -1.2 & $1.45 \mathrm{E}-02$ \\
\hline GRAMD1C & -2.4 & $2.35 \mathrm{E}-03$ & RNLS & -1.2 & $3.01 \mathrm{E}-02$ \\
\hline LONRF1 & -2.3 & $8.31 \mathrm{E}-04$ & ACVR2A & -1.2 & $2.05 \mathrm{E}-03$ \\
\hline PPM1L & -2.3 & $2.20 \mathrm{E}-02$ & CEP68 & -1.2 & $2.05 \mathrm{E}-02$ \\
\hline GLRX & -2.2 & $2.43 \mathrm{E}-03$ & DYNC1LI1 & -1.1 & $6.22 \mathrm{E}-03$ \\
\hline ITGBL1 & -2.2 & $2.18 \mathrm{E}-02$ & TANC1 & -1.1 & $1.34 \mathrm{E}-02$ \\
\hline FAM13C & -2.2 & $1.07 \mathrm{E}-02$ & ATG2B & -1.1 & $1.21 \mathrm{E}-03$ \\
\hline MATN2 & -2.2 & $3.13 \mathrm{E}-02$ & WDFY3 & -1.1 & $2.97 \mathrm{E}-02$ \\
\hline CADM1 & -2.2 & $1.36 \mathrm{E}-02$ & KIAA1012 & -1.0 & $1.57 \mathrm{E}-02$ \\
\hline GAS7 & -2.2 & $9.34 \mathrm{E}-04$ & NARG1L & -1.0 & $2.57 \mathrm{E}-02$ \\
\hline TRAM1L1 & -2.2 & $4.33 \mathrm{E}-02$ & & & \\
\hline I 02 & & & & \\
\hline
\end{tabular}

Abbreviations: $\mathrm{AK}=$ actinic keratosis; $\mathrm{ANOVA}=$ analysis of variance; $\mathrm{cSCC}=$ cutaneous squamous cell carcinoma; $F C=$ fold change. 


\begin{tabular}{|c|c|c|c|c|c|}
\hline $\begin{array}{l}\text { Gene } \\
\text { name }\end{array}$ & $\begin{array}{c}\log 2 \\
\text { FC }\end{array}$ & $\begin{array}{c}\text { Adj } \\
P \text {-value }\end{array}$ & $\begin{array}{l}\text { Gene } \\
\text { name }\end{array}$ & $\begin{array}{c}\log 2 \\
\text { FC }\end{array}$ & $\begin{array}{c}\text { Adj } \\
P \text {-value }\end{array}$ \\
\hline MMP1 & 4.6 & $3.46 \mathrm{E}-02$ & CDC42BPB & 1.4 & $6.22 \mathrm{E}-03$ \\
\hline MMP10 & 4.4 & $3.77 \mathrm{E}-04$ & S100A6 & 1.4 & $4.56 \mathrm{E}-02$ \\
\hline CXCL1 & 4.1 & $7.91 \mathrm{E}-04$ & IL4R & 1.4 & $1.33 E-02$ \\
\hline INHBA & 3.7 & 6.07E- 03 & SPATS2 & 1.4 & $3.72 \mathrm{E}-02$ \\
\hline SPP1 & 3.7 & $7.91 \mathrm{E}-04$ & $\mathrm{ZCCHC} 10$ & 1.4 & $1.33 E-02$ \\
\hline PTHLH & 3.5 & $7.81 \mathrm{E}-04$ & SRM & 1.4 & $4.39 \mathrm{E}-02$ \\
\hline SH2D5 & 3.5 & $2.91 \mathrm{E}-03$ & JAG1 & 1.4 & $4.14 \mathrm{E}-02$ \\
\hline ALDH1A3 & 3.3 & $1.85 \mathrm{E}-02$ & JOSD1 & 1.4 & $1.43 E-02$ \\
\hline LAMC2 & 3.1 & $2.35 E-03$ & $Z Y X$ & 1.3 & $2.76 \mathrm{E}-02$ \\
\hline GPRC5A & 2.9 & $3.88 \mathrm{E}-02$ & NOLC1 & 1.3 & $2.87 \mathrm{E}-02$ \\
\hline PLAUR & 2.8 & $3.77 \mathrm{E}-04$ & GLT25D1 & 1.3 & $3.03 E-02$ \\
\hline GPR68 & 2.7 & $2.17 \mathrm{E}-02$ & CTSB & 1.3 & $2.97 \mathrm{E}-02$ \\
\hline STC1 & 2.3 & $4.33 \mathrm{E}-02$ & YKT6 & 1.3 & $2.90 \mathrm{E}-02$ \\
\hline ERO1L & 2.2 & $3.46 \mathrm{E}-03$ & HIST1H2BI & 1.3 & $2.37 \mathrm{E}-02$ \\
\hline ANXA2 & 2.2 & $1.97 \mathrm{E}-02$ & HN1L & 1.3 & $4.53 E-02$ \\
\hline MTHFD1L & 2.2 & $1.43 E-02$ & FLNB & 1.3 & $2.95 \mathrm{E}-02$ \\
\hline SLC16A3 & 2.2 & $1.33 E-03$ & MAP3K13 & 1.3 & $3.75 \mathrm{E}-02$ \\
\hline EIF4EBP1 & 2.2 & $1.64 \mathrm{E}-02$ & PLEC1 & 1.3 & $1.73 E-02$ \\
\hline PLAU & 2.2 & $6.31 \mathrm{E}-03$ & RPS6KA4 & 1.3 & $2.05 E-03$ \\
\hline FLNA & 2.1 & $1.08 \mathrm{E}-03$ & IFRD2 & 1.3 & $1.19 \mathrm{E}-02$ \\
\hline IGF2BP2 & 2.1 & $2.35 \mathrm{E}-03$ & ANKLE2 & 1.2 & $2.97 \mathrm{E}-02$ \\
\hline ITGA5 & 2.1 & $8.31 \mathrm{E}-04$ & TSC2 & 1.2 & $3.32 \mathrm{E}-02$ \\
\hline HRH1 & 2.1 & $4.20 \mathrm{E}-02$ & SLC9A1 & 1.2 & $5.44 \mathrm{E}-04$ \\
\hline KLF7 & 2.1 & $8.19 E-03$ & TES & 1.2 & $2.16 \mathrm{E}-02$ \\
\hline FAM83A & 2.0 & $2.16 \mathrm{E}-02$ & LRRC8A & 1.2 & $3.01 \mathrm{E}-02$ \\
\hline TRIP10 & 2.0 & $7.15 E-03$ & N4BP1 & 1.2 & $6.07 \mathrm{E}-03$ \\
\hline NRP2 & 2.0 & $1.85 \mathrm{E}-02$ & DNAJC8 & 1.2 & $7.11 \mathrm{E}-03$ \\
\hline PDIA5 & 2.0 & $2.43 E-03$ & PLOD1 & 1.2 & $1.96 \mathrm{E}-03$ \\
\hline SERPINB1 & 2.0 & $1.45 \mathrm{E}-02$ & S100A13 & 1.2 & $2.88 \mathrm{E}-02$ \\
\hline SRGAP1 & 1.9 & $1.43 E-02$ & PDXK & 1.2 & $3.30 \mathrm{E}-02$ \\
\hline TYMP & 1.9 & $2.29 E-02$ & TCF3 & 1.1 & $3.34 \mathrm{E}-03$ \\
\hline SESTD1 & 1.8 & $2.88 \mathrm{E}-02$ & $P V R$ & 1.1 & $3.63 E-03$ \\
\hline RASIP1 & 1.8 & $1.57 \mathrm{E}-02$ & VPS72 & 1.1 & $1.08 \mathrm{E}-02$ \\
\hline C11orf17 & 1.8 & $1.72 \mathrm{E}-02$ & PAK2 & 1.1 & $1.22 \mathrm{E}-02$ \\
\hline NOP56 & 1.8 & $1.40 \mathrm{E}-02$ & $C A D$ & 1.1 & $2.26 \mathrm{E}-02$ \\
\hline C16orf57 & 1.8 & $1.05 \mathrm{E}-02$ & RUVBL1 & 1.1 & $4.06 \mathrm{E}-02$ \\
\hline TGFA & 1.7 & $1.19 \mathrm{E}-02$ & TICAM1 & 1.1 & $3.63 E-03$ \\
\hline MET & 1.7 & $5.00 \mathrm{E}-03$ & B4GALT1 & 1.1 & $1.57 \mathrm{E}-02$ \\
\hline CARHSP1 & 1.7 & $1.05 \mathrm{E}-02$ & GPR153 & 1.1 & $8.57 \mathrm{E}-04$ \\
\hline ZAK & 1.7 & $5.44 \mathrm{E}-04$ & HNRNPU & 1.1 & $2.97 \mathrm{E}-02$ \\
\hline HN1 & 1.7 & $2.11 \mathrm{E}-02$ & ZNF697 & 1.1 & $7.15 E-03$ \\
\hline FTL & 1.6 & $1.84 \mathrm{E}-02$ & CDC27 & 1.0 & $1.55 E-03$ \\
\hline TNFRSF12A & 1.6 & $7.15 E-03$ & MARK3 & 1.0 & $3.52 \mathrm{E}-02$ \\
\hline CDCP1 & 1.6 & $7.66 \mathrm{E}-03$ & CEBPD & 1.0 & $4.02 \mathrm{E}-02$ \\
\hline RFTN1 & 1.6 & $3.30 \mathrm{E}-02$ & $A P 2 A 2$ & 1.0 & $3.34 \mathrm{E}-03$ \\
\hline KLF6 & 1.6 & $4.74 \mathrm{E}-02$ & ZBED4 & 1.0 & $3.98 \mathrm{E}-02$ \\
\hline TRIO & 1.6 & $4.06 \mathrm{E}-02$ & CTSLL3 & 1.0 & $1.69 \mathrm{E}-02$ \\
\hline EHD2 & 1.5 & $4.73 E-02$ & BRD9 & 1.0 & $3.86 \mathrm{E}-02$ \\
\hline
\end{tabular}

\section{Table 2B. (Continued)}

\begin{tabular}{|l|c|c|l|c|c|}
\hline $\begin{array}{l}\text { Gene } \\
\text { name }\end{array}$ & $\begin{array}{c}\text { Log2 } \\
\text { FC }\end{array}$ & $\begin{array}{c}\text { Adj } \\
\boldsymbol{P} \text {-value }\end{array}$ & $\begin{array}{l}\text { Gene } \\
\text { name }\end{array}$ & $\begin{array}{c}\text { Log2 } \\
\text { FC }\end{array}$ & $\begin{array}{c}\text { Adj } \\
\boldsymbol{P} \text {-value }\end{array}$ \\
\hline TCOF1 & 1.5 & $4.57 \mathrm{E}-02$ & SF3A2 & 0.9 & $1.33 \mathrm{E}-03$ \\
\hline NRIP3 & 1.5 & $3.34 \mathrm{E}-03$ & HEATR2 & 0.9 & $3.75 \mathrm{E}-02$ \\
\hline CDH3 & 1.5 & $2.60 \mathrm{E}-02$ & RFT1 & 0.9 & $2.06 \mathrm{E}-02$ \\
\hline JUN & 1.5 & $1.50 \mathrm{E}-02$ & SOCS1 & 0.8 & $1.28 \mathrm{E}-02$ \\
\hline CDC20 & 1.5 & $6.14 \mathrm{E}-03$ & GTSE1 & 0.8 & $3.77 \mathrm{E}-04$ \\
\hline RRBP1 & 1.5 & $2.17 \mathrm{E}-02$ & GALE & 0.7 & $2.37 \mathrm{E}-02$ \\
\hline BOP1 & 1.4 & $1.73 \mathrm{E}-02$ & ATP13A1 & 0.7 & $4.89 \mathrm{E}-02$ \\
\hline SDC4 & 1.4 & $4.89 \mathrm{E}-02$ & VPS37B & 0.6 & $3.72 \mathrm{E}-02$ \\
\hline VEGFA & 1.4 & $4.12 \mathrm{E}-02$ & & & \\
\hline
\end{tabular}

Abbreviations: $\mathrm{AK}=$ actinic keratosis; $\mathrm{ANOVA}=$ analysis of variance; $\mathrm{cSCC}=$ cutaneous squamous cell carcinoma; $F C=$ fold change.

All procedures were performed according to the manufacturer's recommended protocol. Raw data for all samples are available through the Gene Expression Omnibus (GEO: http:// www.ncbi.nlm.nih.gov/geo/), accession number GSE45216.

Statistical analysis. Quality control analysis was performed as recommended for Affymetrix microarrays using the R/Bioconductor statistical programming environment (Tumor Analysis Best Practices Working Group, 2004). All subsequent data analysis procedures were also performed in R. Data were normalised using GCRMA and filtered using a variance of $\geqslant 0.1$. Differential gene expression analysis was performed using the normalised and filtered set of probes with ANOVA and eBayes. An adjusted $P \leqslant 0.05$ after correction for multiple testing (BenjaminiHochberg) was considered as significantly different between the two groups. Gene set enrichment analysis (GSEA) was performed as previously described using the $\mathrm{C} 1, \mathrm{C} 2, \mathrm{C} 3$ and $\mathrm{C} 5$ gene sets (Subramanian et al, 2005; Hamoudi et al, 2010). Leading edge analysis was performed to identify the most biologically important genes within sets that were identified as differentially regulated between AK and SCC. Gene ontology (GO) was performed using the online bioinformatic tool DAVID. To assess the effect of differentiation status and immune status on the expression profile, unsupervised hierarchical clustering of the GCRMA normalised and filtered probes $(n=22926)$ was performed using Ward average linkage. A Fisher's exact test was used to measure the compactness of clustering for each variable.

Quantitative real-time PCR. Quantitative real-time PCR (qRT-PCR) was performed on an independent set of biopsies. Total RNA was extracted from fresh-frozen biopsies by homogenisation under liquid nitrogen. In total, RNA was extracted from five normal skin samples, nine AKs, nine WD SCC and 9 MD SCC using the RNeasy Mini kit with on-column DNAse digestion (Qiagen, Manchester, UK) according to the manufacturer's instructions. First-strand cDNA was synthesised from $500 \mathrm{ng}$ RNA using Superscript III First-Strand Synthesis SuperMix, with a combination of $2.5 \mu \mathrm{M}$ oligo dT and random primers $\left(2.5 \mathrm{ng} \mu \mathrm{l}^{-1}\right)$ (Invitrogen, Paisley, UK). cDNA was diluted 1:10 before real-time quantitative PCR (QPCR) analysis. Quantitative PCRs were run in triplicate on the ABI 7500 Real time PCR machine (Invitrogen) using $1 \mu \mathrm{l}$ diluted cDNA and Brilliant II SYBR Green QPCR Mastermix (Stratagene, Wokingham, UK) with the two-step cycling protocol recommended by the manufacturer. The PCR primers were intron spanning with the exception of those for JUN, which has a single exon (primer sequences are available in Supplementary methods). Relative expression data were calculated by the equation $2^{\Delta \Delta \mathrm{Ct}}$, using the endogeneous control gene RPS9 as 
the internal reference. Data were normalised to the mean Ct value from five normal (non-lesional) skin samples. For each sample, cDNA synthesis was also performed in the absence of reverse transcriptase to exclude the possibility of genomic contamination. Statistical analysis was performed using a two-tailed $t$-test, with a $P<0.05$ considered as statistically significant.

\section{RESULTS}

Genes involved in epidermal differentiation, angiogenesis, taxis, proliferation and adhesion are differentially expressed between AK and cSCC. To identify DEGs between AK and cSCC, expression microarray data from $30 \mathrm{cSCC}$ and $10 \mathrm{AKs}$ were analysed by two different statistical algorithms: ANOVA and eBayes (Supplementary Table 1). The probes that were identified as differentially expressed by both methods were considered as a robust set of DEGs between AK and cSCC (adjusted $P<0.05$ ). In total, this included 239 probes (131 were upregulated in the cSCC and 108 were downregulated), which corresponded to 196 annotated genes (Tables $2 \mathrm{~A}$ and $\mathrm{B}$ ). This probe list notably included two upregulated genes that have been consistently identified as overexpressed in cSCC from previous microarray studies (MMP1 and $C D H 3)$, as well as downregulation of the differentiation-specific keratin, KRT10, which is also consistently reported in cSCC (Van Haren et al, 2009).

Clustering of the samples using these probes revealed two main groups, one containing the majority of CSCC (20 out of 30$)$ and the second containing the $\mathrm{AK}$ and remaining $10 \mathrm{cSCC}$ (Figure 1). The cluster containing only cSCC included $73 \%$ (11 out of 15) of the MD-PD tumours, compared with $40 \%$ (6 out of 15) of the WD tumours, although this difference did not reach statistical significance using a two-tailed Fisher's exact test. There were no other significant clinical or pathological features relating to age at diagnosis, gender, immune status or tumour location (sun exposed $v s$ non-sun exposed) that accounted for separation of the cSCC across the two groups. Careful laser capture microdissection of tissue samples used for RNA extraction makes it unlikely that stromal contamination was responsible for the clustering of some cSCC with the AK samples. Rather, it may indicate that there is a spectrum of tumour development. AK10 was clustered on an outlying clade within the same cluster as the other AK samples. There were no outstanding clinical or pathological features of this case (male, aged 80, immunocompetent, sun-exposed site) that accounted for its position within the clustering, again suggesting that it could represent natural variation among the samples.

To identify biological processes represented by the DEGs, GO was performed using the online bioinformatic tool, DAVID. This revealed terms associated with angiogenesis, epidermal development and differentiation, taxis, proliferation and adhesion (Supplementary Table 2). In keeping with these ontology terms, some of the genes that showed the largest fold-change downregulation in the cSCC were those involved in terminal epidermal differentiation, including filaggrin ( $F L G)$, filaggrin family member 2 (FLG2), loricrin (LOR) and late cornified envelope 1B (LCE1B). Those that were strongly upregulated in CSCC included the matrix metallopeptidases $M M P 1$ and $M M P 10$, and a set of genes associated with migration and focal adhesion (including filamin A (FLNA), FLNB, integrin alpha 5 (ITGA5), jun proto-oncogene (JUN), met proto-oncogene, laminin-5 gamma2 chain (LAMC2), p21 protein (Cdc42/Rac)-activated kinase 2 (PAK2), vascular endothelial growth factor A (VEGFA) and Zyxin (ZYX).

qRT-PCR validates microarray differential gene expression analysis. To validate the findings of the microarray analysis, eight genes identified by both statistical methods (ACVR2A, ID4, INHBA, JUN, MET, MMP10, PAK2 and PTHLH) were assessed

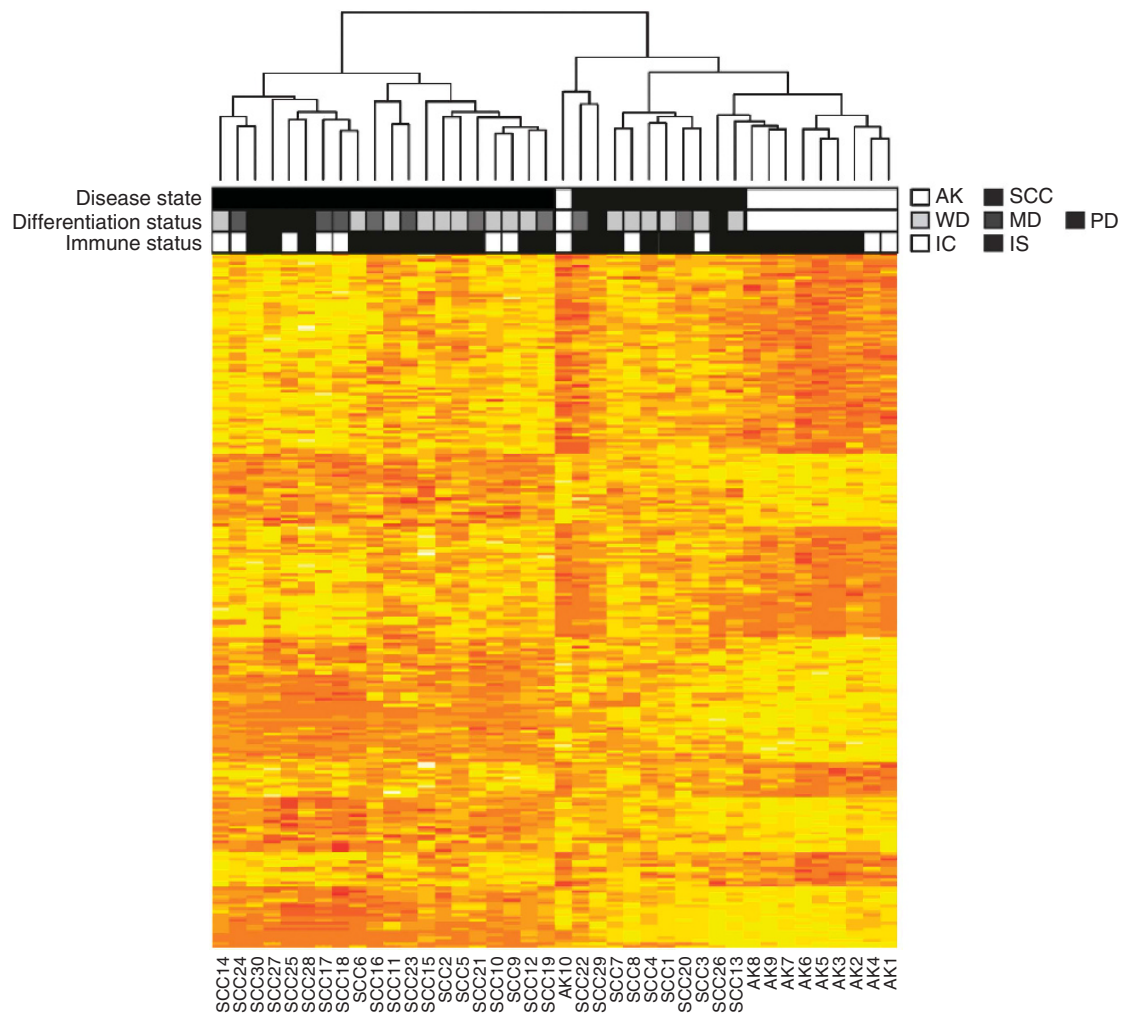

Figure 1. Heat map of 239 overlapping differentially expressed probes identified by ANOVA and eBayes analysis of cSCC vs AK. Characterisation bars beneath the dendrogram highlight key clinicopathological variables. Abbreviations: $\mathrm{AK}=$ actinic keratosis; $\mathrm{IC}=$ immunocompetent; $\mathrm{IS}=$ immunosuppressed; $\mathrm{MD}=$ moderately differentiated; $\mathrm{PD}=$ poorly differentiated; $\mathrm{SCC}=\mathrm{squamous}$ cell carcinoma; $\mathrm{WD}=$ well differentiated. 
by qRT-PCR in an independent series of 27 lesions (9 AKs, 9 WD SCC and 9 MD SCC). In addition, a further three genes that were identified by the ANOVA only were validated (ADAM17, ANXA1 and PLK1), as well as MAPK1 that was identified by eBayes only. In all cases, the qRT-PCR data confirmed significant upregulation or downregulation between the AK and either the WD SCC, MD SCC or combined values ( $\mathrm{WD}+\mathrm{MD}$ ), suggesting good reliability for the genes identified by this microarray study (Figure 2).

GSEA identifies overrepresentation of members of the MAPK pathway genes in cSCC. GSEA was performed to investigate the expression of genes within a priori established gene sets, to identify whether a group of genes that share a defined category (such as biological function, pathway or chromosomal location) show collective differences in expression between AK and cSCC. This is a useful tool for extrapolating biologically relevant information from microarray studies, and is particularly robust as it focuses on a group of genes that share a category, rather than individual genes that may be subject to signal-to-noise background. In total, 28 significantly enriched gene sets were identified $(P \leqslant 0.05$, FDR $<0.25$ ). These could be broadly classified into four categories: signal transduction or apoptosis, cell cycle or replication, metabolic processes or cell motility and miscellaneous (which included gene sets related to the expression profile of other cancer types) (Table 3; Figure $3 \mathrm{~A}$ and $\mathrm{B}$ ). Analysis of the leading edge genes underlying the enrichment of each individual gene set revealed that many were consistently represented, suggesting that they strongly influenced the expression pattern in SCC. These included multiple members of the MAPK family (including JUN, FOS, MET, MAPK1, MAP2K2 and $M A P 3 K 5)$ and the apoptotic response (including $P A K 2, B A X$, $D E D D, D A X X$ and $D F F A$ ), suggesting that the interplay of the MAPK pathway and apoptotic response may be a critical determinant of AK to cSCC progression. No gene sets were identified from chromosomal and cytogenetic locations or conserved cis-regulatory motifs.

WD tumours display a distinct expression profile to MD and PD cSCC. To investigate the effect of different variables on the expression profile of the SCC, unsupervised hierarchical clustering of the cSCC only was performed. This revealed two main clusters: cluster 1 contained predominantly WD tumours and cluster 2 contained mostly MD and PD tumours (Figure 3C). The clusters show that WD tumours form the most significant cluster $(P=0.002)$ with 13 out of $15(86.7 \%)$ WD tumours in cluster 1 , clearly separating them from the majority of MD and PD tumours (Figure 3D). Moderately differentiated and PD tumours themselves form weaker clusters ( $P=0.05$ and $P=0.06$, respectively), however when combined they show a highly significant clustering pattern $(P=0.002)$. This is in keeping with the histological heterogeneity of higher grade SCC, which often shows areas of varying differentiation rather than a consistent differentiation status across the whole tumour. Immune status showed no influence on clustering across all tumours, with around half of each status present in both clusters $(P=0.55$ for both).
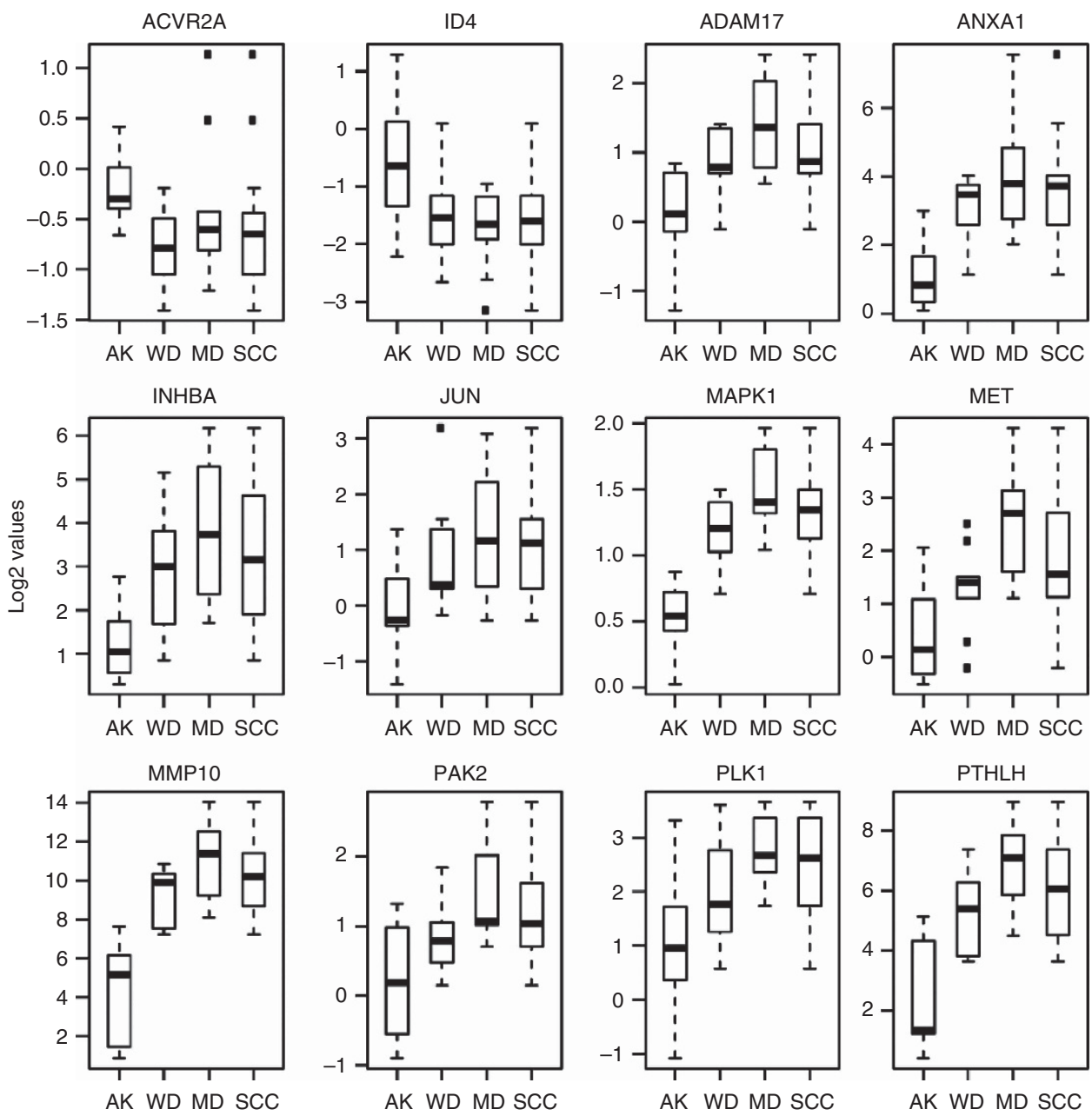

Figure 2. qRT-PCR analysis of 12 differentially expressed genes between AK and cSCC. Solid black squares indicate outlier samples. For the purposes of comparison, the CSCC has been split into WD and MD categories, as well as overall values (SCC). Abbreviations: $A K=$ actinic keratosis; $\mathrm{MD}=$ moderately differentiated; $\mathrm{SCC}=$ squamous cell carcinoma; $\mathrm{WD}=$ well differentiated. 


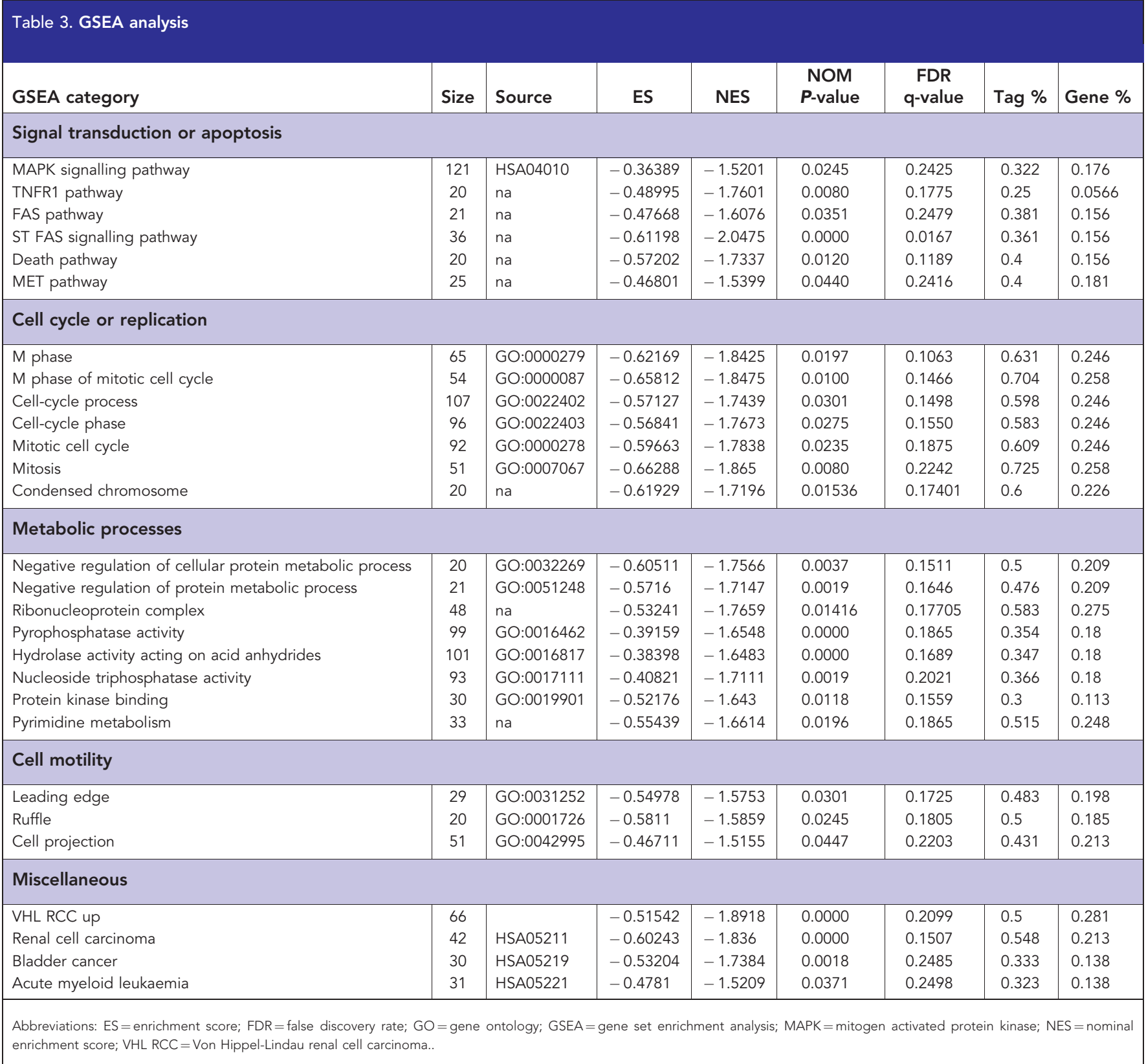

Differential gene expression analysis (eBayes and ANOVA) identified no DEGs between WD cSCC and their MD/PD counterparts after correction for multiple testing, likely due to the small number of samples in each subgroup. Similarly, no genes were identified as differentially expressed between tumours from immunosuppressed $v s$ immunocompetent patients (examined within the category of WD cSCC only to avoid bias from the differentiation status of the tumours).

\section{DISCUSSION}

Cutaneous SCC is the most highly mutated of all cancers, and consequently displays a complex genetic background (Durinck et al, 2011). Our study identified a set of 196 DEGs between AK and cSCC, with enrichment for genes involved in loss of differentiation (including downregulation of FLG, FLG2, LOR, $L C E 1 B, K R T 9$ and KRT10 in cSCC), and gain of invasive properties such as extracellular matrix remodelling and cell migration. We have identified the MAPK pathway as pivotal to many of these processes, and specifically found the oncogenes JUN and MET to be overexpressed in cSCC. This is particularly significant as the contribution of oncogenes to cSCC development has remained elusive, despite the identification of a number of key tumour suppressor genes such as TP53, CDKN2A and, recently, NOTCH (Jonason et al, 1996; Brown et al, 2004; Durinck et al, 2011; Wang et al, 2011). Furthermore, we have shown that WD cSCC display a distinct expression profile to $\mathrm{MD}$ or $\mathrm{PD}$ tumours, which has implications for future targeted therapies.

Actinic keratoses represent a precancerous stage in cSCC genesis, and provide an opportunity to characterise processes relevant to the progression of skin carcinogenesis. Many previous expression microarray studies of the transition from AK to cSCC have identified few $(<10)$, or no, DEGs between these two disease states (Nindl et al, 2006; Padilla et al, 2010; Ra et al, 2011). In a systematic review of six microarrays studies, it was suggested that the low consensus for differential gene expression in CSCC resulted from 

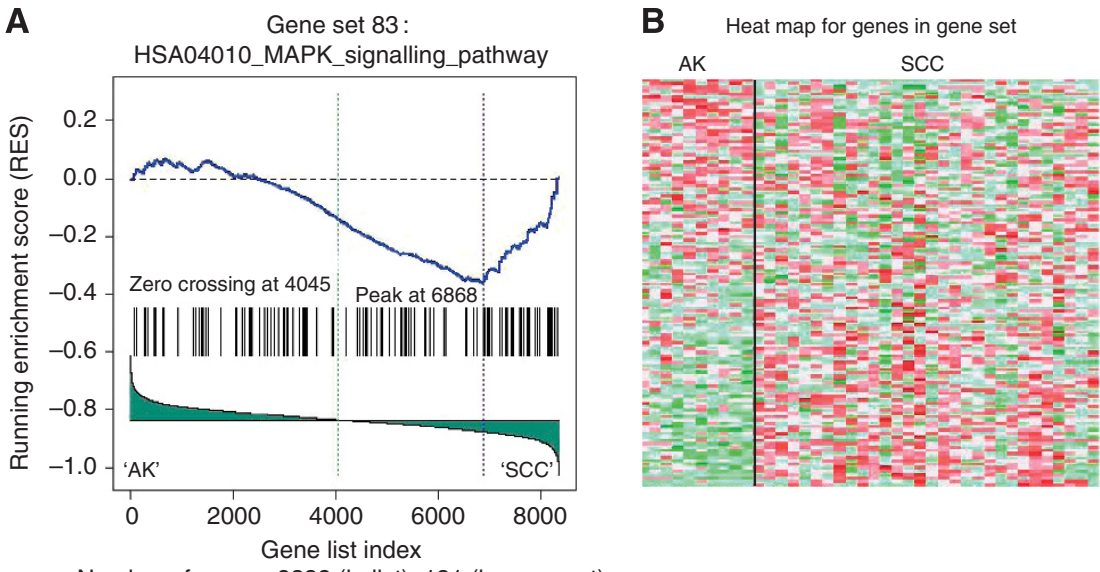

Number of genes: 8338 (in list), 121 (in gene set)

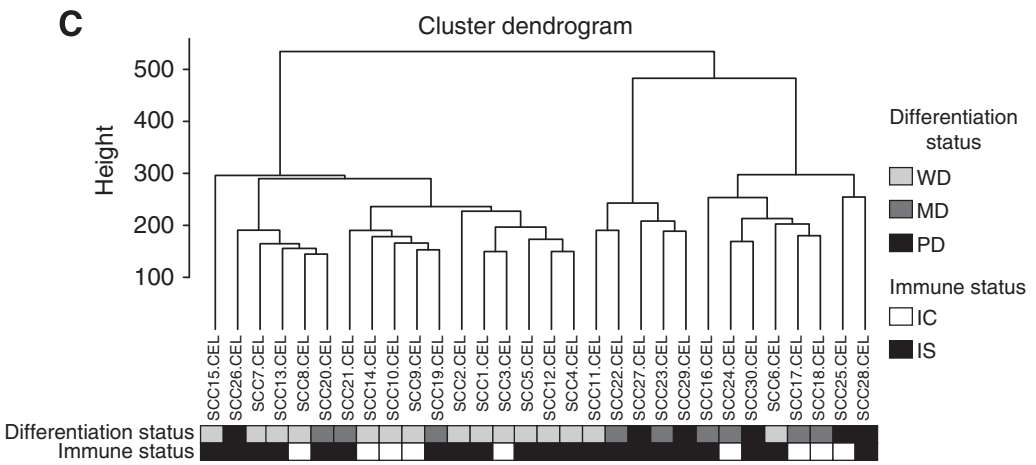

Figure 3. Enrichment of differences in the MAPK signalling pathway (HSA04010) between AK and cSCC as identified by GSEA, and cluster analysis of cSCC. (A) Enrichment of genes in the MAPK signalling pathway. The blue line indicates the enrichment score (ES) and the black vertical lines beneath correspond to individual genes within the set, ranked according to their enrichment. If no enrichment was present, then the genes would be distributed equally from left to right. (B) Heat map of the enriched genes, showing their level of expression across AK and cSCC. Red indicates high expression and green indicates low expression. Each row corresponds to a gene within the MAPK gene set, while each column corresponds to an individual sample. (C) Cluster dendrogram revealing two main clusters of cSCC, separated predominantly by differentiation status (WD vs M/PD). Abbreviations: $A K=$ actinic keratosis; $I C=$ immunocompetent; $I S=$ immunosuppressed; $M D=$ moderately differentiated; $\mathrm{PD}=$ poorly differentiated; $\mathrm{SCC}=$ squamous cell carcinoma; $\mathrm{WD}=$ well differentiated.

clinical and methodological differences, including small sample sizes, tissue processing, different baseline comparators (normal skin or AK) and varied bioinformatic approaches (Van Haren et al, 2009). Importantly, the findings from our study are consistent with recently published work that combined laser capture microdissection with reverse phase protein microarray analysis (Einspahr et al, 2012). This study also identified activation of the MAPK pathway in CSCC compared with AK and normal skin, highlighting the power of stringent laser capture microdissection for improved consistency across studies. In addition, a further study that focused on a smaller series of AK and cSCC from OTRs also identified the MAPK pathway to be activated in cSCC (Hameetman et al, 2013). Although we cannot be sure the individual AK used across these studies had the potential to progress, the pattern of differential expression supports consistent differences in the biology of these tumours with a shift in invasive properties between AK and cSCC.

MAPK pathway in cSCC. The oncogenes MET, JUN and PAK2 were all overexpressed in cSCC compared with AK. Both MET and JUN are direct components of the MAPK pathway, which was identified by GSEA to be a key difference between AK and cSCC. MAPK signalling has a central role in regulating growth and survival of cancer cells, and the RAF/MEK/ERK pathway is dysregulated in approximately one-third of human cancers (Dhillon et al, 2007). Consequently, a number of small molecule inhibitors have been designed to target specific steps in MAPK signalling (including MET) and are now in clinical trials (Tu et al, 2010). The potential importance of this pathway in cSCC has recently been highlighted by the rapid development of cSCC in a proportion of patients treated with the multi-kinase inhibitor, Sorafenib, or the selective BRAF V600E inhibitors, Vemurafenib and Dabrafenib (Ribas and Flaherty, 2011). There is evidence that this is caused by paradoxical activation of the MAPK pathway, which is proposed to cooperate with pre-existing somatic UVinduced mutations in key oncogenes and tumour suppressors such as H-RAS and TP53 (Hatzivassiliou et al, 2010; Heidorn et al, 2010; Poulikakos et al, 2010; Arnault et al, 2012).

We also observed strong upregulation of the collagenase MMP1 and the stromeolysin MMP10 in CSCC, both of which are associated with invasion and metastasis via degradation of ECM proteins (Overall and Kleifeld, 2006). MMP1 upregulation is one of the few consistent findings across multiple cSCC microarray studies and, similar to targets in the MAPK pathway, has therapeutic potential for inhibition (Van Haren et al, 2009; Gialeli et al, 2011). In addition, pro-metastatic molecules such as PTHLH and osteopontin (SPP1) were upregulated in our data set, whereas putative tumour suppressors such as RORA, PDZD2 and AZGP1 were found to be downregulated (Tam et al, 2008; Yip et al, 2011; Wang et al, 2012).

Transcriptome profiles reflect histological subtypes of cutaneous SCC. Histological subtypes of cSCC are associated with distinct clinical characteristics and behaviour, with poor differentiation an 
independent prognostic factor for metastatic potential (Mourouzis et al, 2009; Breuninger et al, 2012; Jambusaria-Pahlajani et al, 2013). We have previously shown that WD cSCC display a distinct genetic profile to $\mathrm{MD}$ and $\mathrm{PD}$ tumours, with fewer genomic aberrations overall (Purdie et al, 2009). In addition, single gene-specific studies have reported differential expression or genomic aberration patterns between cSCC of different histological grades, including higher expression of $L R I G-1$ in WD cSCC, an association of PTPRD deletions with PD cSCC and overexpression of Survivin in PD tumours (Lo Muzio et al, 2001; Tanemura et al, 2005; Lambert et al, 2012). Our transcriptome data support the genomic profiling by finding that WD tumours display a distinct expression profile to MD and PD cSCC. While we were unable to identify specific genes that are differentially expressed between the subgroups (most likely due to small sample numbers), our data imply that the histological subtypes of cSCC should be defined when addressing the molecular pathogenesis, prevention and treatment of these tumours.

In conclusion, our study is the first to describe widespread transcriptome changes between precancerous AK and cSCC in both immunocompetent and immunosuppressed individuals. These data highlight several known oncogenes, and reveal a broad spectrum of disrupted cellular processes that are altered in cSCC. The MAPK pathway shows pivotal changes, and offers a new approach to targeted preventative and therapeutic strategies. Finally, our data indicate that histological subtypes of cSCC represent distinct entities at the transcriptome level, and may in the future require individually tailored therapeutic approaches.

\section{ACKNOWLEDGEMENTS}

We would like to thank Cancer Research UK, the European Research Council, the British Skin Foundation and Barts and the London Charitable Trust for funding, and the Paterson Institute for Cancer Research for microarray processing.

\section{CONFLICT OF INTEREST}

The authors declare no conflict of interest.

\section{REFERENCES}

Arnault JP, Mateus C, Escudier B, Tomasic G, Wechsler J, Hollville E, Soria JC, Malka D, Sarasin A, Larcher M, Andre J, Kamsu-Kom N, Boussemart L, Lacroix L, Spatz A, Eggermont AM, Druillennec S, Vagner S, Eychene A, Dumaz N, Robert C (2012) Skin tumors induced by sorafenib; paradoxic RAS-RAF pathway activation and oncogenic mutations of HRAS, TP53, and TGFBR1. Clin Cancer Res 18(1): 263-272.

Ashton KJ, Weinstein SR, Maguire DJ, Griffiths LR (2003) Chromosomal aberrations in squamous cell carcinoma and solar keratoses revealed by comparative genomic hybridization. Arch Dermatol 139(7): 876-882.

Breuninger H, Brantsch K, Eigentler T, Hafner HM (2012) Comparison and evaluation of the current staging of cutaneous carcinomas. J Dtsch Dermatol Ges 10(8): 579-586.

Brown VL, Harwood CA, Crook T, Cronin JG, Kelsell DP, Proby CM (2004) p16INK4a and p14ARF tumor suppressor genes are commonly inactivated in cutaneous squamous cell carcinoma. J Invest Dermatol 122(5): 1284-1292.

Clausen OP, Aass HC, Beigi M, Purdie KJ, Proby CM, Brown VL, Mattingsdal M, Micci F, Kolvraa S, Bolund L, Deangelis PM (2006) Are keratoacanthomas variants of squamous cell carcinomas? A comparison of chromosomal aberrations by comparative genomic hybridization. J Invest Dermatol 126(10): 2308-2315.

Criscione VD, Weinstock MA, Naylor MF, Luque C, Eide MJ, Bingham SF (2009) Actinic keratoses: natural history and risk of malignant transformation in the Veterans Affairs Topical Tretinoin Chemoprevention Trial. Cancer 115(11): 2523-2530. de Vries E, van de Poll-Franse LV, Louwman WJ, de Gruijl FR, Coebergh JW (2005) Predictions of skin cancer incidence in the Netherlands up to 2015. Br J Dermatol 152(3): 481-488.

Dhillon AS, Hagan S, Rath O, Kolch W (2007) MAP kinase signalling pathways in cancer. Oncogene 26(22): 3279-3290.

Durinck S, Ho C, Wang NJ, Liao W, Jakkula LR, Collisson EA, Pons J, Chan SW, Lam ET, Chu C, Park K, Hong SW, Hur JS, Huh N, Neuhaus IM, Yu SS, Grekin RC, Mauro TM, Cleaver JE, Kwok PY, LeBoit PE, Getz G, Cibulskis K, Aster JC, Huang H, Purdom E, Li J, Bolund L, Arron ST, Gray JW, Spellman PT, Cho RJ (2011) Temporal dissection of tumorigenesis in primary cancers. Cancer Discov 1(2): 137-143.

Einspahr JG, Calvert V, Alberts DS, Curiel-Lewandrowski C, Warneke J, Krouse R, Stratton SP, Liotta L, Longo C, Pellacani G, Prasad A, Sagerman P, Bermudez Y, Deng J, Bowden GT, Petricoin 3rd EF (2012) Functional protein pathway activation mapping of the progression of normal skin to squamous cell carcinoma. Cancer Prev Res (Phila) 5(3): 403-413.

Euvrard S, Kanitakis J, Claudy A (2003) Skin cancers after organ transplantation. N Engl J Med 348(17): 1681-1691.

Skin Care Foundation (2010) Skin Cancer Foundation Vol. 2010. Skin Care Foundation: New York

Frost C, Williams G, Green A (2000) High incidence and regression rates of solar keratoses in a queensland community. J Invest Dermatol 115(2): 273-277.

Gialeli C, Theocharis AD, Karamanos NK (2011) Roles of matrix metalloproteinases in cancer progression and their pharmacological targeting. FEBS J 278(1): 16-27.

Tumor Analysis Best Practices Working Group (2004) Expression profilingbest practices for data generation and interpretation in clinical trials. Nat Rev Genet 5(3): 229-237.

Haider AS, Peters SB, Kaporis H, Cardinale I, Fei J, Ott J, Blumenberg M, Bowcock AM, Krueger JG, Carucci JA (2006) Genomic analysis defines a cancer-specific gene expression signature for human squamous cell carcinoma and distinguishes malignant hyperproliferation from benign hyperplasia. J Invest Dermatol 126(4): 869-881.

Hameetman L, Commandeur S, Bavinck JN, Wisgerhof HC, de Gruijl FR, Willemze R, Mullenders L, Tensen CP, Vrieling H (2013) Molecular profiling of cutaneous squamous cell carcinomas and actinic keratoses from organ transplant recipients. BMC Cancer 13: 58.

Hamoudi RA, Appert A, Ye H, Ruskone-Fourmestraux A, Streubel B, Chott A, Raderer M, Gong L, Wlodarska I, De Wolf-Peeters C, MacLennan KA, de Leval L, Isaacson PG, Du MQ (2010) Differential expression of NF-kappaB target genes in MALT lymphoma with and without chromosome translocation: insights into molecular mechanism. Leukemia 24(8): 1487-1497.

Harwood CA, Mesher D, McGregor JM, Mitchell L, Leedham-Green M, Raftery M, Cerio R, Leigh IM, Sasieni P, Proby CM (2013) A surveillance model for skin cancer in organ transplant recipients: a 22-year prospective study in an ethnically diverse population. Am J Transplant 13(1): 119-129.

Harwood CA, Proby CM, McGregor JM, Sheaff MT, Leigh IM, Cerio R (2006) Clinicopathologic features of skin cancer in organ transplant recipients: a retrospective case-control series. J Am Acad Dermatol 54(2): 290-300.

Hatzivassiliou G, Song K, Yen I, Brandhuber BJ, Anderson DJ, Alvarado R, Ludlam MJ, Stokoe D, Gloor SL, Vigers G, Morales T, Aliagas I, Liu B, Sideris S, Hoeflich KP, Jaiswal BS, Seshagiri S, Koeppen H, Belvin M, Friedman LS, Malek S (2010) RAF inhibitors prime wild-type RAF to activate the MAPK pathway and enhance growth. Nature 464(7287): 431-435.

Heidorn SJ, Milagre C, Whittaker S, Nourry A, Niculescu-Duvas I, Dhomen N, Hussain J, Reis-Filho JS, Springer CJ, Pritchard C, Marais R (2010) Kinasedead BRAF and oncogenic RAS cooperate to drive tumor progression through CRAF. Cell 140(2): 209-221.

Jambusaria-Pahlajani A, Kanetsky PA, Karia PS, Hwang WT, Gelfand JM, Whalen FM, Elenitsas R, Xu X, Schmults CD (2013) Evaluation of AJCC Tumor Staging for cutaneous squamous cell carcinoma and a proposed alternative tumor staging system. JAMA Dermatol 149(4): 402-410.

Jonason AS, Kunala S, Price GJ, Restifo RJ, Spinelli HM, Persing JA, Leffell DJ, Tarone RE, Brash DE (1996) Frequent clones of p53-mutated keratinocytes in normal human skin. Proc Natl Acad Sci USA 93(24): 14025-14029.

Kathpalia VP, Mussak EN, Chow SS, Lam PH, Skelley N, Time M, Markelewicz Jr RJ, Kanduc D, Lomas L, Xiang Z, Sinha AA (2006) Genome-wide transcriptional profiling in human squamous cell carcinoma of the skin identifies unique tumor-associated signatures. J Dermatol 33(5): 309-318. 
Kraus DH, Carew JF, Harrison LB (1998) Regional lymph node metastasis from cutaneous squamous cell carcinoma. Arch Otolaryngol Head Neck Surg 124(5): 582-587.

Lambert SR, Harwood CA, Purdie KJ, Gulati A, Matin RN, Romanowska M, Cerio R, Kelsell DP, Leigh IM, Proby CM (2012) Metastatic cutaneous squamous cell carcinoma shows frequent deletion in the protein tyrosine phosphatase receptor Type D gene. Int J Cancer 131(3): E216-E226.

Lo Muzio L, Staibano S, Pannone G, Mignogna MD, Mariggio A, Salvatore G, Chieffi P, Tramontano D, De Rosa G, Altieri DC (2001) Expression of the apoptosis inhibitor survivin in aggressive squamous cell carcinoma. Exp Mol Pathol 70(3): 249-254.

Madan V, Lear JT, Szeimies RM (2010) Non-melanoma skin cancer. Lancet 375(9715): 673-685.

Memon AA, Tomenson JA, Bothwell J, Friedmann PS (2000) Prevalence of solar damage and actinic keratosis in a Merseyside population. Br J Dermatol 142(6): 1154-1159.

Mourouzis C, Boynton A, Grant J, Umar T, Wilson A, Macpheson D, Pratt C (2009) Cutaneous head and neck SCCs and risk of nodal metastasis-UK experience. J Craniomaxillofacial Surg 37(8): 443-447.

Nindl I, Dang C, Forschner T, Kuban RJ, Meyer T, Sterry W, Stockfleth E (2006) Identification of differentially expressed genes in cutaneous squamous cell carcinoma by microarray expression profiling. Mol Cancer 5: 30.

Overall CM, Kleifeld O (2006) Tumour microenvironment-opinion: validating matrix metalloproteinases as drug targets and anti-targets for cancer therapy. Nat Rev Cancer 6(3): 227-239.

Padilla RS, Sebastian S, Jiang Z, Nindl I, Larson R (2010) Gene expression patterns of normal human skin, actinic keratosis, and squamous cell carcinoma: a spectrum of disease progression. Arch Dermatol 146(3): 288-293.

Popp S, Waltering S, Herbst C, Moll I, Boukamp P (2002) UV-B-type mutations and chromosomal imbalances indicate common pathways for the development of Merkel and skin squamous cell carcinomas. Int J Cancer 99(3): 352-360.

Poulikakos PI, Zhang C, Bollag G, Shokat KM, Rosen N (2010) RAF inhibitors transactivate RAF dimers and ERK signalling in cells with wild-type BRAF. Nature 464(7287): 427-430.

Purdie KJ, Harwood CA, Gulati A, Chaplin T, Lambert SR, Cerio R, Kelly GP, Cazier JB, Young BD, Leigh IM, Proby CM (2009) Single nucleotide polymorphism array analysis defines a specific genetic fingerprint for well-differentiated cutaneous SCCs. J Invest Dermatol 129(6): 1562-1568.

Purdie KJ, Lambert SR, Teh MT, Chaplin T, Molloy G, Raghavan M, Kelsell DP, Leigh IM, Harwood CA, Proby CM, Young BD (2007) Allelic imbalances and microdeletions affecting the PTPRD gene in cutaneous squamous cell carcinomas detected using single nucleotide polymorphism microarray analysis. Genes Chromosomes Cancer 46(7): 661-669.

Quinn AG, Sikkink S, Rees JL (1994) Basal cell carcinomas and squamous cell carcinomas of human skin show distinct patterns of chromosome loss. Cancer Res 54(17): 4756-4759.
Ra SH, Li X, Binder S (2011) Molecular discrimination of cutaneous squamous cell carcinoma from actinic keratosis and normal skin. Mod Pathol 24(7): 963-973.

Ribas A, Flaherty KT (2011) BRAF targeted therapy changes the treatment paradigm in melanoma. Nat Rev Clin Oncol 8(7): 426-433.

Rogers HW, Weinstock MA, Harris AR, Hinckley MR, Feldman SR, Fleischer AB, Coldiron BM (2010) Incidence estimate of nonmelanoma skin cancer in the United States, 2006. Arch Dermatol 146(3): 283-287.

Rowe DE, Carroll RJ, Day Jr. CL (1992) Prognostic factors for local recurrence, metastasis, and survival rates in squamous cell carcinoma of the skin, ear, and lip. Implications for treatment modality selection. J Am Acad Dermatol 26(6): 976-990.

Subramanian A, Tamayo P, Mootha VK, Mukherjee S, Ebert BL, Gillette MA, Paulovich A, Pomeroy SL, Golub TR, Lander ES, Mesirov JP (2005) Gene set enrichment analysis: a knowledge-based approach for interpreting genome-wide expression profiles. Proc Natl Acad Sci USA 102(43): 15545-15550.

Tam CW, Liu VW, Leung WY, Yao KM, Shiu SY (2008) The autocrine human secreted PDZ domain-containing protein 2 (sPDZD2) induces senescence or quiescence of prostate, breast and liver cancer cells via transcriptional activation of p53. Cancer Lett 271(1): 64-80.

Tanemura A, Nagasawa T, Inui S, Itami S (2005) LRIG-1 provides a novel prognostic predictor in squamous cell carcinoma of the skin: immunohistochemical analysis for 38 cases. Dermatol Surg 31(4): 423-430.

Tu WH, Zhu C, Clark C, Christensen JG, Sun Z (2010) Efficacy of c-Met inhibitor for advanced prostate cancer. BMC cancer 10: 556.

Van Haren R, Feldman D, Sinha AA (2009) Systematic comparison of nonmelanoma skin cancer microarray datasets reveals lack of consensus genes. Br J Dermatol 161(6): 1278-1287.

Wang NJ, Sanborn Z, Arnett KL, Bayston LJ, Liao W, Proby CM, Leigh IM, Collisson EA, Gordon PB, Jakkula L, Pennypacker S, Zou Y, Sharma M, North JP, Vemula SS, Mauro TM, Neuhaus IM, Leboit PE, Hur JS, Park K, Huh N, Kwok PY, Arron ST, Massion PP, Bale AE, Haussler D, Cleaver JE, Gray JW, Spellman PT, South AP, Aster JC, Blacklow SC, Cho RJ (2011) Loss-of-function mutations in Notch receptors in cutaneous and lung squamous cell carcinoma. Proc Natl Acad Sci USA 108(43): 17761-17766.

Wang Y, Solt LA, Kojetin DJ, Burris TP (2012) Regulation of p53 stability and apoptosis by a ROR agonist. PLoS One 7(4): e34921.

Yip PY, Kench JG, Rasiah KK, Benito RP, Lee CS, Stricker PD, Henshall SM, Sutherland RL, Horvath LG (2011) Low AZGP1 expression predicts for recurrence in margin-positive, localized prostate cancer. Prostate 71(15): $1638-1645$.

This work is published under the standard license to publish agreement. After 12 months the work will become freely available and the license terms will switch to a Creative Commons AttributionNonCommercial-Share Alike 3.0 Unported License.

Supplementary Information accompanies this paper on British Journal of Cancer website (http://www.nature.com/bjc) 